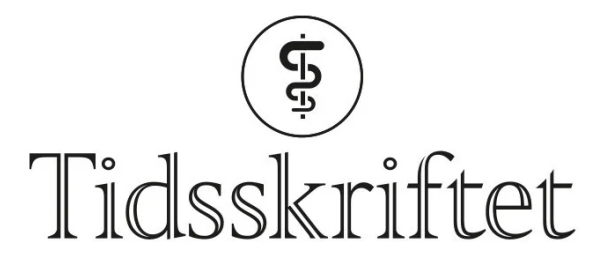

DEN NORSKE LEGEFORENING

\title{
Smertebehandling gir færre atferdsproblemer
}

NYHETER

\section{ERLEND HEM}

Email: erlend.hem@medisin.uio.no

Tidsskriftet

\section{Individualisert smertebehandling har effekt på atferdsproblemer hos sykehjemspasienter med moderat og alvorlig demens.}

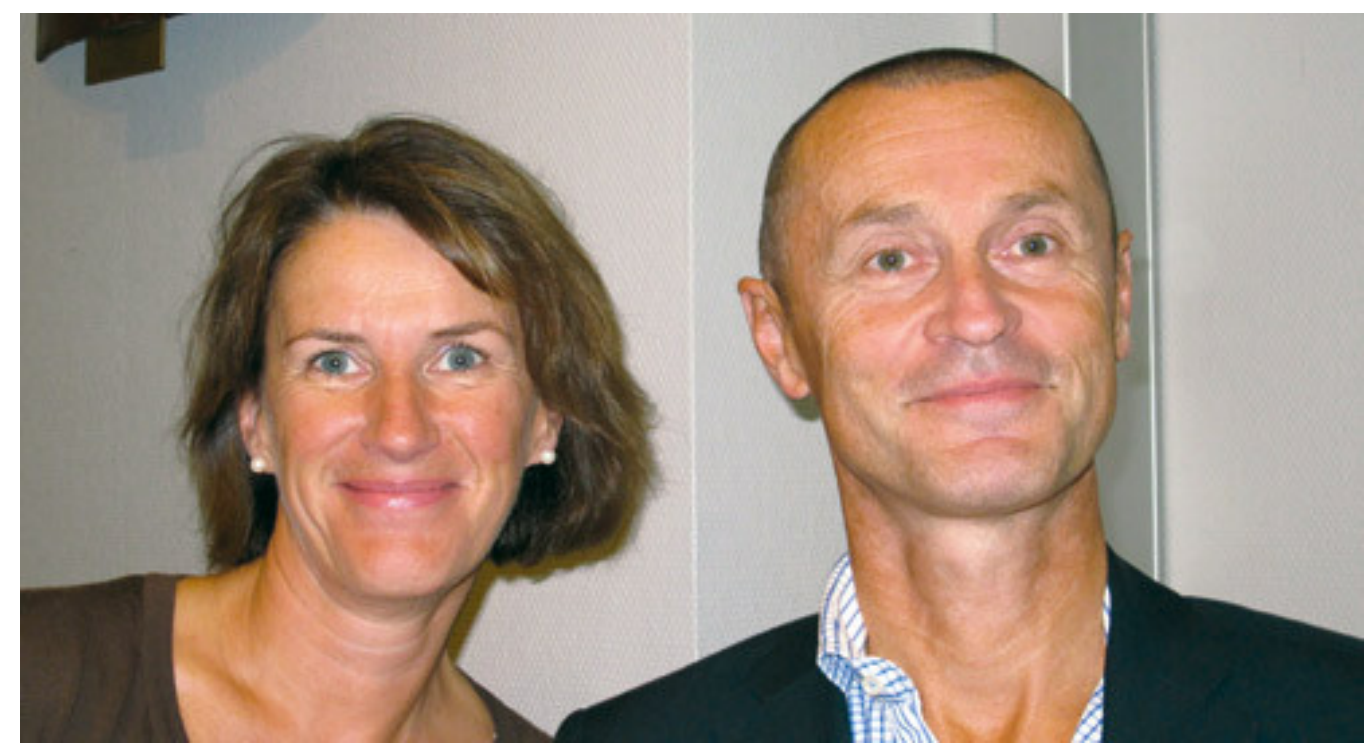

Førsteforfatter Bettina S. Husebø og sisteforfatter Dag Aarsland. Foto privat Agitasjon og aggresjon er hyppige og belastende symptomer hos sykehjemspasienter med demens. Atferdsproblemene behandles ofte med antipsykotika til tross for hyppige bivirkninger og liten eller ingen dokumentert effekt. Pasienter med langkommet demens er ofte ikke i stand til å kommunisere smerte pga. redusert hukommelse, språkbeherskelse og refleksjonsevne. Underdiagnostisert og underbehandlet smerte er forbundet med $\emptyset$ kende atferdsproblemer.

En norsk studie, gjennomført fra oktober 2009 til juni 2010, omfattet 60 sykehjemsavdelinger fra 18 sykehjem på Vestlandet. $35^{2}$ pasienter med moderat eller alvorlig demens og atferdsproblemer ble randomisert enten til en trinnvis protokoll med 
smertebehandling eller til en kontrollgruppe med vanlig behandling. Begge grupper fikk for øvrig samme grad av oppmerksomhet og oppfølging. $70 \%$ av deltakerne fikk paracetamol, $20 \%$ buprenorfinplaster pga. svelgevansker, $10 \%$ morfin eller pregabalin. Kontrollgruppen fortsatte med vanlig behandling. Effekten ble målt med standardiserte måleinstrumenter for agitasjon (CMAI), psykiatriske symptomer (NPI-NH) og smerte (MOBID-2) etter åtte ukers behandling og fire uker etter avsluttet intervensjon.

- Analysene viste signifikant reduksjon av atferdsproblemer i intervensjonsgruppen etter åtte ukers behandling. Gjennomsnittlig CMAI-reduksjon var $17 \%$, noe som tilsvarer effekten man tidligere har vist av risperidon, som er eneste godkjente medikament for behandling av agitasjon hos demente. Smertebehandling viste også positiv effekt på variablene NPI-NH og MOBID-2, sier postdoktor Bettina S. Husebø ved Institutt for samfunnsmedisinske fag, Universitetet i Bergen.

- Det er mulig at agitasjon avtok pga. morfinpreparaters beroligende effekt. Imidlertid var det bare $25 \%$ som fikk slik behandling, og kun tre pasienter ble ekskludert pga. tretthet. Deltakerne var heller ikke forandret med tanke på daglige aktiviteter eller kognitiv funksjon.

Resultatene understreker betydningen av å vurdere og behandle smerte som del av behandling og forebygging av agitasjon og aggresjon hos pasienter med demens. Effektiv smertebehandling kan sannsynligvis også medføre en reduksjon i bruken av antipsykotika og andre psykofarmaka.

\section{Smerte- og demensforskning}

Artikkelen er skrevet av Bettina S. Husebø, Clive Ballard, Reidun Sandvik, Odd Bjarte Nilsen og Dag Aarsland. Studien var et samarbeid mellom Universitetet i Bergen, Senter for eldremedisin og samhandling (SESAM) ved Stavanger universitetssjukehus, Karolinska Institutet og King's College, London. 


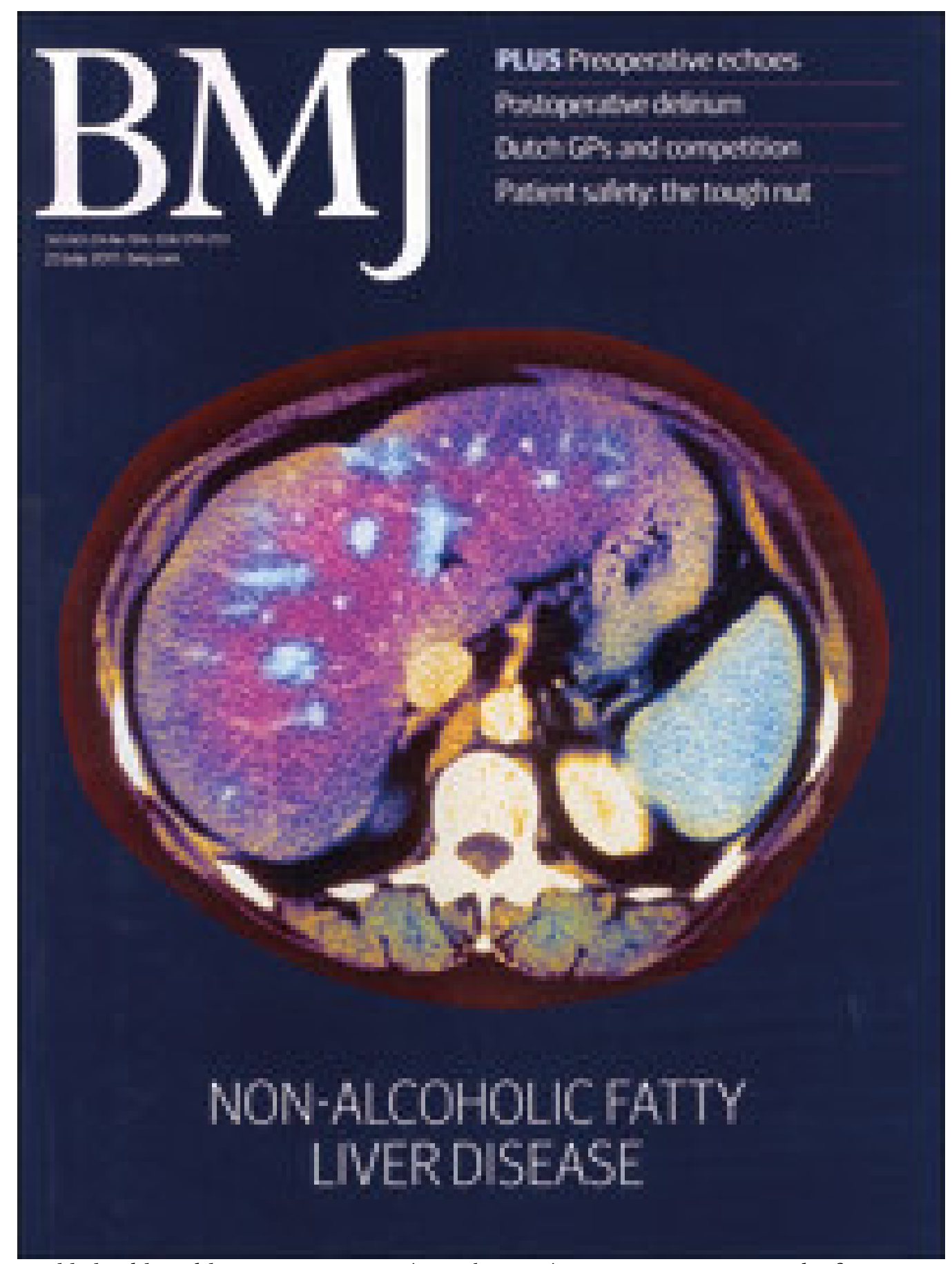

Artikkelen ble publisert 15.7. 2011 i BMJ (www.bmj.com), som regnes som en av de "fem store» innen medisinsk publisering ved siden av New England Journal of Medicine, JAMA, Annals of Internal Medicine og The Lancet

\section{Ordforklaringer}

CMAI: Cohen-Mansfield Agitation Inventory: registrerer 29 forskjellige psykiatriske atferdstegn hos pasienter med demens

NPI-NH: Neuropsychiatric Inventory - Nursing Home Version: fanger opp nevropsykiatriske symptomer

MOBID-2: Mobilisation-Observation-Behaviour-Intensity-Dementia-2: smerteskala som ble utviklet og testet i Bettina S. Husebøs doktorgradsprosjekt for å evaluere smerte hos pasienter med moderat og alvorlig demens 
1. Husebo BS, Ballard C, Sandvik R et al. Efficacy of treating pain to reduce behavioural disturbances in residents of nursing homes with dementia: cluster randomised clinical trial. BMJ 2011;343: d4065.

Publisert: 29. november 2011. Tidsskr Nor Legeforen. DOI: 10.4045/tidsskr.11.1171

(C) Tidsskrift for Den norske legeforening 2023. Lastet ned fra tidsskriftet.no 26. april 2023. 